Situs Jurnal : $\underline{\text { http://ejournal.stiepancasetia.ac.id/index.php/jieb }}$

Jilid 6 Nomor 1 Maret 2020

Hal 26 - 37

\title{
PERANAN PERILAKU SOSIAL PT. ARMADA MIX BANJARBARU SEBAGAI BENTUK PERTANGGUNGJAWABAN SOSIAL PERUSAHAAN TERHADAP LINGKUNGAN SEKITARNYA
}

\author{
YUDI RAHMAN
}

Sekolah Tinggi Ilmu Ekonomi PancasetiaJl. Ahmad Yani Km. 5,5 RT. 08 Lantai 2 \& 3 Telp. (0511)

3256560 Fax. (0511) 3256557 Banjarmasin - 70248

\begin{abstract}
Abstrak
Tujuan dari penelitian ini untuk mengetahui peranan perilaku Sosial pada PT. Armada Mix Banjarbaru sebagai bentuk pertanggungjawaban sosial perusahaan terhadap lingkungan sekitar perusahaan yang dijalankan dan dilakukan perusahaan selama ini sehingga dapat memberikan masukan mengenai esensial konsep akuntansi pertanggungjawaban sosial yang seharusnya dilakukan sesuai dengan teori yang dilakukan. Metode yang digunakan adalah metode deskripsi yaitu menggambarkan mengenai bagaimana perlakuan terhadap perilaku yang dilakukan perusahaan yang terkonsep dalam pertanggungjawaban sosial yang dilakukan secara Pengukuran dan Pelaporan Akuntansi Pertanggungjawaban Sosial. Dalam melakukan penelitian ini, penulis menggunakan metode pengumpulan data dengan cara observasi, wawancara dan dokumentasi.

Dari penelitian yang telah dilaksanakan, penulis memperoleh hasil penelitian bahwa apa yang dilakukan perusahaan PT. Armada Mix Banjarbaru telah melakukan beberapa aktivitasaktivitas berupa kontribusi perusahaan kepada masyarakat, kontribusi perusahaan terhadap lingkungan hidup dan kontribusi perusahaan terhadap sumber daya manusia. serta kontribusi perusahaan terhadap produk dan jasa. Dan tentunya perusahaan juga dapat melakukan Pengukuran dan Pelaporan Akuntansi Pertanggungjawaban Sosial yang terkonsep melalui Pendekatan Deskriptif, Pendekatan biaya yang dikeluarkan dan Pendekatan biaya manfaat sehingga dengan penerapan yang dilakukan akan membawa perubahan untuk perusahaan berupa konsep akuntansi pertanggungjawaban yang baik.
\end{abstract}

Kata Kunci :Peranan Perilaku social, pertanggungjawaban social dan lingkungan Sekitar 


\section{Pendahuluan}

\subsection{Latar Belakang}

Perusahaan yang baik selalu mempunyai misi dan tujuan tertentu yang luhur serta tidak sekedar mencari keuntungan, akan tetapi harus dapat meningkatkan standar hidup masyarakat dan membuat hidup manusia lebih manusiawi melalui pemenuhan kebutuhan secara baik. Sehingga perusahaan yang hanya mencari keuntungan telah menyebabkan perilaku yang menjurus menghalalkan segala cara demi mencari keuntungan yang sebesar-besarnya tanpa mengindahkan nilai-nilai manusiawi lainnya.

PT. Armada Mix Banjarbaru bergerak dalam bidang penyedia cor beton curah siap pakai atau ready mix concrete yang pada umumnya digunakan oleh perusahaan perusahaan kontraktor dan konsumen umum untuk mempermudah serta mempersingkat waktu pekerjaan pengecoran bangunan gedung, jalan dan jembatan. Sekarang ini PT. Armada Mix Banjarbaru dihadapkan pada persaingan global dengan linkungan yang berubah secara cepat. Perekonomian kapitalis yang pada prakteknya sering mengabaikan kepentingan sosial dan lingkungan, perlahan namun pasti sudah mulai mengadopsi nilai-nilai sosial yang ada sehingga perlu penerapan akuntansi pertanggungjawaban sosial pada perusahaan tersebut dan tentunya akuntansi pertanggungjawaban sosial yang akan dilaksanakan tidak terlepas dari kesadaran perusahaan terhadap kepentingan lain selain untuk memaksimalkan laba bagi perusahaan. Perusahaan menyadari bahwa mereka selalu bersinggungan dengan berbagai kontroversi dan masalah sosial sehingga perusahaan mulai memperhartikan hubungan dengan lingkungan sosial.

Namun dalam penerapan akuntansi pertanggungjawaban sosial pasti akan mengalami berbagai kendala, terutama dalam masalah pengukuran elemen-elemen sosial dan dalam rangka penyajiannya di laporan keuangan yang bersifat kuantitatif. masalah pengukuran timbul terutama karena tidak semua elemen sosial dapat diukur dengan satuan uang serta belum terdapatnya standar akuntansi yang baku mengenai pengukuran dan pelaporan pelaksanaan tanggung jawab sosial perusahaan, sehingga diharapkan Akuntansi pertanggungjawaban yang merupakan bagian dari dunia usaha ikut memberikan kontribusi dalam merespon kepedulian sosial perusahaan dengan berkembangnya akuntansi sosial termasuk didalamnya pengungkapan aktivitas sosial dalam laporan keuangan tahunan perusahaan.

\subsection{Rumusan Masalah}

Berdasar latar belakang masalah yang telah diuraikan diatas maka, penulis merumuskan beberapa permasalahan antara lain :

1.Bagaimanakah perilaku sosial pada perusahaan dalam melaksanakan semua aktivitas-aktivitasnya yang dilakukan terhadap lingkungan sekitarnya?

2.Bagaimanakah laporan akuntansi pertanggung jawaban sosial untuk menilai kinerja sosial perusahaan pada PT. Armada Mix Banjarbaru?

\subsection{Tujuan Penelitian}

Adapun tujuan penelitian ini adalah.

1. Untuk mengetahui perilaku sosial perusahaan terhadap lingkungan sekitarnya dalam melaksanakan aktivitas-aktivitasnya.

2. Untuk mengetahui laporan akuntansi pertanggung jawaban sosial untuk

JIEB, Jilid 6, No 1,19 Maret 2020 ISSN Online 2615-2134 
menilai kinerja sosial pada PT. Armada Mix Banjarbaru.

\subsection{Manfaat Penelitian}

Penulisan penelitian ini diharapkan memiliki manfaat sebagai berikut :

1. Bermanfaat bagi pembaca dalam menambah wawasan tentang penerapan akuntansi pertanggungjawaban sosial yang dapat dilakukan pada suatu perusahaan.

2. Bermanfaat untuk membantu manajemen perusahaan untuk menyusun suatu laporan tentang biaya-biaya sosial dan laporan nilai tambah sebagai pelengkap dalam laporan keuangan untuk menunjukkan pertanggungjawaban sosial perusahaan.

3. Sebagai referensi bagi pihak lain yang akan melakukan penelitian lebih lanjut mengenai topik ini.

\section{Tinjauan Pustaka}

\subsection{Definisi Akuntansi Pertanggung jawaban Sosial}

Menurut Harahap (2005 : 184): "Ilmu

Socio Economic Accounting (SEA) merupakan bidang ilmu akuntansi yang berfungsi dan mencoba mengidentifikasi mengukur, menilai, melaporkan aspek aspek Social Benefit dan Social Cost yang ditimbulkan oleh lembaga".

Definisi akuntansi pertanggung jawaban sosial menurut Belkaoui (2009:339) adalah sebagai berikut : "Proses pengurutan, pengukuran dan pengungkapan pengaruh yang kuat dari pertukaran antara suatu perusahaan dengan lingkungan sosialnya". Sedangkan menurut Lee sebagaimana yang dikutip oleh Usmansyah (2009 : 33) menyatakan bahwa secara esensial mengenai konsep akuntansi pertanggungjawaban sosial adalah suatu perluasan dari prinsip, praktek, dan terutama keahlian dari akuntan dan akuntansi konvensional.

\subsection{Ruang Lingkup Akuntansi Pertanggung jawaban Sosial}

Menurut Harahap (2005 : 198 - 200), keterlibatan sosial perusahaan yang disesuaikan dengan keadaan di Negara Indonesia yaitu :

1. Lingkungan hidup, antara lain : pengawasan terhadap efek polusi, perbaikan pengrusakan alam, konservasi alam, keindahan lingkungan, pengurangan suara bising, penggunaan tanah, pengelolaan sampah dan air limbah, riset dan pengembangan lingkungan, kerja sama dengan energi, antara lain : konservasi energi yang dilakukan perusahaan, penghematan energi dalam proses produksi dan lainlain.

2. Sumber Daya manusia dan Pendidikan, antara lain : keamanan dan kesehatan karyawan, pendidikan karyawan, kebutuhan keluarga dan rekreasi karyawan, menambah dan memperluas hak-hak karyawan, usaha untuk mendorong partisipasi, perbaikan pensiun, beasiswa, bantuan pada sekolah, pendirian sekolah, membantu pendidikan tinggi, riset dan pengembangan, pengangkatan pegawai dari kelompok miskin, peningkatan karir karyawan dan lain-lain.

3. Praktek Bisnis yang Jujur, antara lain : memperhatikan hak-hak karyawan wanita, jujur dalam iklan, kredit, servis, produk, jaminan, selalu mengontrol kualitas produk, dan lain-lain, pemerintah dan universitas, pembangunan lokasi rekreasi dan lainlain.

4. Membantu Masyarakat Lingkungan, antara lain : memanfaatkan tenaga ahli perusahaan dalam mengatasi masalah sosial di lingkungannya, tidak campur

JIEB, Jilid 6, No 1,19 Maret 2020 ISSN Online 2615-2134 
tangan dalam struktur masyarakat, membangun klinik kesehatan, sekolah, rumah ibadah, perbaikan desa/kota, sumbangan untuk kegiatan sosial kemasyarakatan, perbaikan perumahan desa, bantuan dana, perbaikan sarana pengangkutan, pasar dan lain-lain.

5. Kegiatan Seni dan Kebudayaan, antara lain: membantu lembaga seni dan budaya,sponsor kegiatan seni dan budaya, penggunaan seni dan budaya dalam iklan, merekrut tenaga yang berbakat seni dan olah raga, dan lainlain.

6. Hubungan dengan Pemegang Saham, antara lain : sifat keterbukaan direksi pada semua persero, peningkatan pengungkapan informasi dalam laporan keuangan, pengungkapan keterlibatan perusahaan dalam kegiatan sosial, dan lain-lain.

7. Hubungan dengan Pemerintah, antara lain : mentaati peraturan pemerintah, membatasi kegiatan lobbying, mengontrol kegiatan politik perusahaan, membantu lembaga pemerintah sesuai dengan kemampuan perusahaan, membantu secara umum usaha peningkatan kesejahteraan sosial masyarakat, membantu proyek dan kebijakan pemerintah, meingkatkan produktivitas sektor informal, pengembangan dan inovasi manajemen dan lain-lain.

\subsection{Pengukuran dan Pelaporan} Akuntansi Pertanggung jawaban Sosial.

Menurut Glautier dan Underdown (2006 : 484 - 485) ada tiga pendekatan yang dapat digunakan untuk pedoman pengukuran dalam pelaporan akuntansi pertanggungjawaban sosial, yaitu :

1. Pendekatan Deskriptif (the descriptive approach)
Pendekatan deskriptif dipandang sebagai pendekatan yang umum digunakan. Dalam laporan sosial deskriptif, informasi mengenai semua aktivitas sosial perusahaan dilaporkan dalam bentuk uraian (deskriptif). Jadi pada pendekatan ini, aktifitas-aktifitas sosial perusahaan dalam pelaporannya tidak dikuantifikasikan dalam satuan uang.

2. Pendekatan biaya yang dikeluarkan (the cost of outlay approach)

Pendekatan biaya yang dikeluarkan menggambarkan semua aktivitasaktivitas sosial perusahaan dikuantifikasikan dalam satuan uang dan menjadi hal yang sebaliknya dari pendekatan deskriptif. Sehingga laporan yang dihasilkan oleh pendekatan biaya yang dikeluarkan mempunyai kemampuan untuk diperbandingkan antara laporan suatu tahun tertentu, dengan laporan tahun yang lain. Sedangkan kelemahannya adalah tidak disajikannya manfaat yang diperoleh sehubungan dengan telah dikeluarkannya biaya untuk suatu kegiatan.

3. Pendekatan biaya manfaat (the cost benefit approach)

Pendekatan biaya manfaat mengungkapkan baik biaya maupun manfaat dari aktivitas-aktivitas sosial perusahaan. Pendekatan biaya manfaat mungkin merupakan pendekatan yang paling ideal. Namun, dalam kenyatannya sulit untuk menerapkannya, antara lain karena tidak adanya alat ukur manfaat dari yang dihasilkan atas biaya yang telah dikeluarkan untuk aktivitas-aktivitas sosial perusahaan.

Bentuk laporan tanggung jawab sosial sampai saat ini belum ada yang baku. Di Amerika, yang merupakan kiblat akuntansi di negara kita, praktek

JIEB, Jilid 6, No 1,19 Maret 2020 ISSN Online 2615-2134 
pelaporannya masih dilaksanakan dengan tidak seragam antara satu perusahaan dengan yang lainnya. Ada yang hanya menyajikan informasi sosial yang bersifat kualitatif sebagai catatan kaki atau keterangan tambahan pada penjelasan laporan keuangan. Ada yang menjalankannya dengan sederhana dan ada yang menjalankannya dengan kompleks.

Menurut Estes seperti yang dikutip oleh Sonhaji (2009: 9) menemukan adanya bermacam-macam praktek pelaporan akuntansi sosial untuk pihak luar. Tiga tingkat cara pelaporan social responsibility accounting lembaga masyarakat, diantaranya adalah :

1. Praktek yang sederhana

Laporan ini hanya terdiri dari uraian yang tidak disertai dengan data kuantitatif,baik satuan uang maupun satuan yang lainnya.

2. Praktek yang lebih maju

Selain yang ditunjukkan dalam metode yang sederhana seperti di atas, juga menggunakan data kuantitatif untuk menunjukkan apa yang sudah dicapai perusahaan

3. Praktek yang paling maju.

Bentuk laporan yang selain berupa uraian data kualitatif dan kuantitatif perusahaan juga menyusun laporannya dalam bentuk neraca.

Menurut Diller seperti yang dikutip oleh Harahap (2002 : 371) ada beberapa teknik pelaporan akuntansi pertanggungjawaban sosial yaitu :

1. Pengungkapan dalam syarat kepada pemegang saham baik dalam laporan tahunan atau bentuk laporan lainnya.

2. Pengungkapan dalam catatan atas laporan keuangan
3. Dibuat dalam perkiraan tambahan misalnya melalui adanya perkiraan (akun) penyisihan kerusakan lokasi, biaya pemeliharaan lingkungan, dan sebagainya.

\subsection{Penelitian Terdahulu}

1.Bahtiar (2013) Hubungan akuntansi pertanggungjawaban dengan efektivitas pengendalian biaya (studi kasus PT. Columbia Cabang Gorontalo. Tujuan penelitian ini adalah untuk mengetahui akuntansi pertanggungjawaban dengan efektivitas pengendalian biaya pada PT. Columbia Cabang Gorontalo. Dan dapat ditarik kesimpulan bahwa diantara akuntansi pertanggung jawaban dengan efektivitas pengendalian biaya dan sifatnya saling berhubungan.

2.Anik Putri (2013) Evaluasi penerapan akuntansi pertanggung jawaban sebagai alat pengendalian biaya produksi pada CV. Anugerah Genteng Manado. Tujuan dari penelitian ini adalah untuk memberikan penjelasan tentang pelaksanaan akuntansi pertanggung jawaban dan mengevaluasi efesiensi pengendalian biaya produksi. Dan hasil penelitian ini diketahui bahwa penerapan akuntansi pertanggung jawaban pada perusahaan belum memadai karena belum ada penggolongan biaya dan pemeberian kode rekening, sehingga penerapan akuntansi pertanggung jawaban belum memadai.

3. Mengko dan Tirayoh (2015) Penerapan akuntansi pertanggung jawaban dengan anggaran sebagai alat pengendalian biaya pada PT Gotrans Cabang Manado. Tujuan penelitian ini adalah untuk mengetahui bagaimana penerapan

JIEB, Jilid 6, No 1,19 Maret 2020 ISSN Online 2615-2134 
akuntansi pertanggungjawaban dengan anggran sebagai alat penegndalian biaya pada perusahaan. Dari hasil penelitian ini menunjukan bahwa penerapan akuntansi pertanggung jawaban belum berjalan dengan baik, dimana manajemen belum menerapkan sepenuhnya unsur- unsur akuntansi pertanggungjawaban dan tidak melakukan secara mendalam atas penyimpangan yang terjadi.

\section{Metode Penelitian}

\subsection{Jenis Penelitian}

Jenis penelitian yang digunakan untuk penelitian ini yaitu penelitian deskriptif. Penelitian deskriptif digunakan jika peneliti ingin memberikan gambaran yang lebih lengkap mengenai suatu fenomena, baik itu fenomena yang sedang berlangsung saat ini, maupun fenomena yang sudah terjadi di masa lalu. Peneliti dapat memberikan gambaran mengenai suatu keadaan saja atau bisa juga mendeskripsikan perkembangan dari keadaan tersebut.

\subsection{Jenis dan Sumber Data}

Jenis data yang digunakan dalam penelitian ini adalah :

1. Kuantitatif, yaitu data dalam bentuk angka-angka seperti informasi biaya dan data-data yang berhubungan dengan masalah yang akan dibahas.

2. Kualitatif, yaitu data yang diperoleh dari objek penelitian dalam bentuk informasi baik secara lisan maupun tulisan seperti struktur organisasi, pembagian tugas, dan lain-lain.

Sumber data yang digunakan dalam penelitian ini adalah:

1. Data primer yaitu data yang dikumpulkan sendiri oleh peneliti dari objek penelitian. Data jenis ini berasal dari observasi, wawancara dan konsultasi terhadap pihak-pihak yang bersangkutan.

2. Data sekunder yaitu data yang diperoleh dari sumber-sumber tertulis berupa data keuangan serta data pendukung lainnya yang berkaitan dengan masalah yang dibahas dalam penulisan ini.

\subsection{Teknik Analisis Data}

Dalam penelitian ini, teknik yang digunakan adalah peranan perilaku sosial terhadap pertanggungjawaban sosial yaitu dengan cara mengumpulkan bahan dan data yang diperlukan untuk kemudian mengolah dan membahasnya.

\subsection{Lokasi Penelitian}

Lokasi penelitian pada Perusahaan PT. Armada Mix Banjarbaru, Jl. Tembus Lingkar Selatan RT 14/RW 04, Kelurahan Landasan Ulin Barat, Kecamatan Lianganggang Kota Banjarbaru Kalimantan Selatan.

\section{Analisis Dan Pembahasan}

\subsection{Prilaku Sosial Perusahaan Dalam} Melaksanakan Aktivitas-aktivitasnya terhadap Lingkungan Sekitarnya.

Sesuai dengan ruang lingkup akuntansi pertanggungjawaban sosial yang diperoleh dari pengamatan peneliti terhadap biaya-biaya yang dikeluarkan perusahaan PT. Armada Mix Banjarbaru, maka aktivitas sosial yang telah dilakukan perusahaan terdiri dari:

a. Kontribusi perusahaan PT. Armada Mix Banjarbaru kepada masyarakat. 
b. Kontribusi perusahaan PT. Armada Mix Banjarbaru terhadap lingkungan hidup

c. Kontribusi perusahaan PT. Armada Mix Banjarbaru terhadap sumber daya manusia.

d. Kontribusi perusahaan PT. Armada Mix Banjarbaru terhadap produk dan jasa.

Dilihat dari apa yang dilakukan perusahaan PT. Armada Mix Banjarbaru tarhadap perannya dilingkungan perusahaan, maka aktivitas- aktivitas tersebut dapat diuraikan sebagai berikut:

1. Kontribusi Perusahaan Armada Mix Banjarbaru kepada masyarakat terdiri dari sumbangan sosial serta bantuan untuk acara hari besar, festival dan hiburan rakyat. Sumbangan sosial yang dikeluarkan oleh perusahaan diantaranya membantu organisasi-organisasi nirlaba, organisasi-organisasi sosial kemasyarakatan dan organisasi warga seperti Rukun Tetangga (RT), Rukun Warga (RW) atau bahkan instansi pemerintah lainnya. Perusahaan sering ikut membantu organisasi-organisasi tersebut yang mengajukan permohonan bantuan dana dan sarana prasarana, serta dukungan lainnya.

2.Sedangkan manfaat lain dari pemberian sumbangan tersebut adalah untuk memberikan biaya kompensasi terhadap masyarakat sekitar yang mungkin terganggu dengan adanya aktifitas perusahaan. Distribusi terhadap lingkungan masyarakat ini dilakukan perusahaan setiap tahun dengan jumlah yang tidak tetap, tergantung dari kebijakan perusahaan.
3. Pada PT. Armada Mix Banjarbaru perusahaan memanfaatkan sumber daya alam untuk beroperasi baik langsung maupun tidak langsung. Sebaliknya, hasil dari operasional tersebut sering menghasilkan efek negatif bagi lingkungan hidup. Itulah sebabnya setiap tahun perusahaan selalu mengeluarkan biaya pemeliharaan lingkungan hidup. Dan juga kesejahteraan karyawan mendapat perhatian khusus dari perusahaan karena hal tersebut berhubungan dengan tingkat produktifitas kerja yang mana secara tidak langsung juga akan berhubungan dengan laba perusahaan.Sehingga perusahaan memperhatikan hal- hal yang berhubungan dengan kesejahteraan karyawan antara lain :

a. Mengikutkan karyawan pada program asuransi Jamsostek.

b. Memberikan pengganti biaya pengobatan untuk karyawan dan keluarga karyawan yang mengalami sakit.

c. Melanjutkan tingkat pendidikan katyawan dan Pelatihan bagi pegawai untuk peningkatan kinerja karyawannya.

d. Memberikan tunjangan kecelakaan kerja dan hari tua kepada karyawan.

e. Penghargaan khusus dan apresiasi bagi karyawan yang berprestasi.

f. Memberikan pesangon kepada karyawan yang telah lepas hubungan kerja dengan pihak perusahaan secara sah.

3. Pada Perusahaan PT. Armada Mix Banjarbaru aktifitas yang berhubungan dengan produk dan jasa antara lain dengan mengadakan

JIEB, Jilid 6, No 1,19 Maret 2020 ISSN Online 2615-2134 


\section{Laporan Biaya Sosial \\ Untuk tahun yang berakhir pada 31 Des 2017 dan 2018}

\begin{tabular}{|c|c|c|}
\hline Uraian & 31-Des-17 & 31-Des-18 \\
\hline \multicolumn{3}{|l|}{ Kontribusi kepada } \\
\hline Sumbangan Sosial & 25.198 .100 & 25.198 .100 \\
\hline Biaya Sponsorship & 2.050 .000 & 3.000 .000 \\
\hline $\begin{array}{l}\text { Total Kontribusi } \\
\text { Kepada Masyarakat }\end{array}$ & 27.248.100 & 28.198 .100 \\
\hline Proporsi (\%) & $\mathbf{9 , 8 7}$ & 10,94 \\
\hline$\frac{\text { Kontribusi kepada }}{\text { Lingkungan Hidup }}$ & & \\
\hline $\begin{array}{l}\text { Pengolahan Limbah } \\
\text { Reklamasi Lahan dan }\end{array}$ & 20.153 .100 & 24.091 .400 \\
\hline Pembuatan taman & 17.030 .900 & 20.130 .900 \\
\hline $\begin{array}{l}\text { Total Kontribusi } \\
\text { kepada Lingkungan } \\
\text { Hidup }\end{array}$ & 37.184.000 & 44.222.300 \\
\hline Proporsi (\%) & 14,93 & 15,47 \\
\hline$\frac{\text { Kontribusi kepada }}{S D M}$ & & \\
\hline Iuran JAMSOSTEK & 15.007 .500 & 20.051 .700 \\
\hline Pengobatan & 22.511 .200 & 40.103 .500 \\
\hline $\begin{array}{l}\text { Pelatihan Pegawai } \\
\text { Pesangon dan }\end{array}$ & 60.030 .000 & 71.452 .900 \\
\hline Sumbangan & 82.541 .200 & 77.850 .800 \\
\hline Penghargaan Khusus & 4.502 .200 & 3.902 .500 \\
\hline $\begin{array}{l}\text { Total Kontribusi } \\
\text { kepada SDM }\end{array}$ & 184.592.100 & 213.361.600 \\
\hline Proporsi (\%) & 74,13 & 74,66 \\
\hline Total Biaya Sosial & 249.024.200 & 285.782.000 \\
\hline $\begin{array}{l}\text { penelitian } \\
\text { terhadap p1 } \\
\text { dihasilkan. } \\
\text { pengembang } \\
\text { terkait der } \\
\text { kenyamanan } \\
\text { menggunaka }\end{array}$ & $\begin{array}{l}\text { dan pen } \\
\text { duk dan } \\
\text { Penelitia } \\
\text { in produk d } \\
\text { gan keam. } \\
\text { konsume } \\
\text { produk dar }\end{array}$ & $\begin{array}{l}\text { embangan } \\
\text { asa yang } \\
\text { dan } \\
\text { nasa ini } \\
\text { nan dan } \\
\text { dalam } \\
\text { jasa yang }\end{array}$ \\
\hline
\end{tabular}

Sumber: Diolah Penulis

Pada PT. Armada Mix Banjarbaru melakukan kontribusi kepada masyarakat dengan menggambarkan peran aktif dihasilkan oleh perusahaan. Hal ini penting dilakukan karena konsumen sebagai pengguna produk dan jasa yang dihasilkan oleh perusahaan pasti akan memilih produk yang aman untuk digunakan bagi mereka. Selain itu riset dan penilaian pasar juga gencar dilakukan agar perusahaan dapat melakukan pemetaan dan perencanaan terhadap pangsa pasar.

\subsection{Laporan Akuntansi Pertanggung jawaban Sosial untuk menilai Kinerja Sosial Perusahaan pada PT. Armada Mix Banjarbaru.}

Pada PT. Armada Mix Banjarbaru perlu melakukan salah satu pendekatan yang digunakan dalam penerapan akuntansi pertanggungjawaban sosial yaitu dengan pendekatan biaya yang dikeluarkan, yang mana dapat menggambarkan semua pengeluaran perusahaan dalam satuan uang untuk setiap kegiatan sosial yang telah dilakukan PT. Armada Mix Banjarbaru

Dalam hal ini PT. Armada Mix Banjarbaru melakukan aktivitas sosial yang dilakukan dan dikelompokkan menjadi empat bagian, yaitu kontribusi perusahaan kepada masyarakat, lingkungan hidup, sumber daya manusia serta produk dan jasa. Pengelompokkan ini didasarkan atas pengamatan terhadap rincian biayabiaya perusahaan. Besarnya kontribusi perusahaan terhadap masing-masing lingkungan sosial untuk tahun 2017 dan 2018 dapat dilihat dalam laporan biaya sosial pada tabel di samping.

perusahaan dalam berinteraksi dengan masyarakat sekitar baik yang bersifat produktif maupun kegiatan sosial. Kelompok biaya sosial ini terdiri dari

JIEB, Jilid 6, No 1,19 Maret 2020 ISSN Online 2615-2134 
sumbangan sosial serta biaya sponsorship (untuk festival atau hiburan rakyat). Kontribusi terhadap lingkungan hidup merupakan partisipasi perusahaan dalam merawat dan memperbaiki kondisi lingkungan hidup. Dalam rincian biaya perusahaan terdapat dua jenis biaya yang termasuk dalam kategori ini, yaitu biaya pengolahan limbah dan biaya reklamasi lahan dan pembuatan taman.

Kontribusi terhadap sumber daya manusia merupakan upaya perusahaan untuk meningkatkan kesejahteraan Proporsi Biaya Sosial terhadap Penjualan Bersih (dalam ribuan)

\begin{tabular}{|l|r|r|c|}
\hline & $\mathbf{2 0 1 7}$ & $\mathbf{2 0 1 8}$ & $\begin{array}{r}\text { Persentasi } \\
\text { Kenaikan }\end{array}$ \\
\hline $\begin{array}{l}\text { Penjualan } \\
\text { Bersih }\end{array}$ & 1.070 .257 & 1.790 .541 & 34,64 \\
\hline Biaya Sosial & 249.024 & 285.782 & 12,86 \\
\hline Proporsi & 0,21 & 0,16 & 0,05 \\
\hline
\end{tabular}

Sumber : Data diolah Penulis

Dari tabel diatas tampak bahwa pada tahun 2017 penjualan bersih perusahaan sebesar Rp. 1.070.257.000 sedangkan biaya sosial yang dialokasikan adalah Rp. 249.024.200 atau 0,21 \% dari penjualan bersih. Sedangkan di tahun 2018 penjualan bersih mengalami kenaikan yang cukup tajam menjadi sebesar Rp.1.790.541.000 atau mengalami kenaikan sebesar 34,64\% dari tahun sebelumnya sehingga alokasi biaya sosialpun mengalami kenaikan menjadi sebesar Rp. 285.782.000 atau mengalami kenaikan sebesar 12,86 \% dari tahun sebelumnya. Sehingga proporsi biaya sosial ditinjau dari jumlah pengeluarannya mengalami kenaikan sebesar Rp. 36.757.800 namun jika dilihat dari prosentase proporsinya biaya sosial mengalami penurunan sebesar $0,05 \%$ dari tahun sebelumnya yaitu menjadi 0,21\%.

Proporsi biaya sosial untuk Kontribusi kepada masyarakat dilihat dari prosentasenya mengalami penurunan pada karyawannya dengan harapan dapat meningkatkan kinerja mereka. Karena dengan meningkatnya kinerja karyawan maka produksi perusahaan dapat meningkat dan akhirnya laba perusahaan menjadi meningkat pula. Iuran Jamsostek, Tunjangan Hari Raya, pengobatan, pelatihan pegawai dan pesangon didapatkan dari biaya tenaga kerja langsung, overhead pabrik, biaya penjualan serta biaya umum dan administrasi. Penghargaan khusus bagi karyawan didapat dari biaya lain-lain.

tahun 2017 dibandingkan menjadi pada tahun 2018, namun dilihat dari jumlahnya mengalami kenaikan hal ini disebabkan oleh kontribusi yang diberikan perusahaan kepada Rukun Tetangga (RT), Rukun Warga (RW) dan instansi pemerintahan lainnya.

Proporsi biaya sosial untuk Kontribusi kepada lingkungan hidup mengalami kenaikan pada tahun 2017 dibandingkan pada tahun 2018. Hal ini dipengaruhi oleh meningkatnya tingkat produksi perusahaan sehingga tingkat pengolahan limbah pun menjadi meningkat hal tersebut juga diikuti dengan peningkatan biaya untuk melakukan perawatan taman dan reklamasi lahan.

Sedangkan reklamasi lahan dan pembuatan tanah dilakukan oleh perusahaan agar lingkungan sekitar perusahaan tetap terjaga keasriannya. Karena dengan meningkatnya aktivitas perusahaan, maka volume polusi udara juga pasti akan meningkat. Namun rekalamasi lahan dan pembuatan taman ini tidak secara langsung dipengaruhi oleh kapasitas produksi perusahaan, karena reklamasi lahan dan pembuatan taman tetap akan dilakukan meskipun kapasitas produksi menurun.

Pada proporsi biaya sosial untuk kontribusi kepada sumber daya manusia. Pada bagian ini walaupun secara jumlah

JIEB, Jilid 6, No 1,19 Maret 2020 ISSN Online 2615-2134 
biaya mengalami kenaikan pada tahun 2017 dibandingkan pada tahun 2018 namun secara prosentase hanya meningkat sebesar $0,53 \%$. Hal ini disebabkan oleh besarnya proporsi untuk kontribusi kepada masyarakat terhadap total biaya sosial. Hal ini sangatlah wajar, mengingat PT. Armada Mix Banjarbaru merupakan perusahaan yang bersifat Labour Insentif sehingga biaya tenaga kerja memiliki jumlah yang besar dalam struktur biayanya.

Peningkatan Iuran JAMSOSTEK dari tahun 2017 dibandingkan dengan tahun 2018 dikarenakan terjadi peningkatan jumlah pegawai pada tahun 2018. Hal ini dilakukan karena terjadi peningkatan permintaan (demand) dari pasar terhadap produk, sehingga mengakibatkan perusahaan mengambil kebijakan untuk penambahan karyawan. Namun peningkatan ini tidak terlalau signifikan jika dibandingkan dengan banyaknya karyawan yang direkrut.

Peningkatan biaya pengobatan karyawan beserta keluarganya pada tahun 2017 dibandingkan pada tahun 2018 tidak secara langsung dipengaruhi oleh meningkatnya volume pada produksi perusahaan, namun dikarenakan komitmen manajemen untuk lebih memperhatikan kesejahteraan semua karyawan beserta keluarganya.

\section{Kesimpulan Dan Saran \\ 5.1 Kesimpulan}

Dari uraian Bab 1 sampai dengan Bab 4 maka dapat ditarik beberapa kesimpulan terhadap perilaku sosial PT. Armada Mix Banjarbaru terhadap lingkungan sekitarnya, Diantaranya adalah:

1. PT. Armada Mix Banjarbaru telah melakukan tanggung jawab sosial terhadap lingkungan sekitarnya yang terkait dengan masyarakat, dengan melakukan kegiatan sebagai berikut:
Peningkatan biaya pelatihan pada tahun 2018 dipengaruhi oleh bertambahnya jumlah pegawai pada tahun tersebut. Sehingga mengharuskan perusahaan untuk melakukan pelatihan bagi karyawankaryawan baru agar karyawan baru tersbut dapat memahami proses produksi yang ada di perusahaan.

Penurunan biaya pesangon dan sumbangan pada tahun 2017 dibandingkan dengan tahun 2018, hal ini disebabkan oleh menurunnya jumlah karyawan yang pensiun atau mengundurkan diri. Hal ini secara tidak langsung disebabkan oleh komitmen perusahaan untuk lebih memperhatikan kesejahteraan karyawan, sehingga karyawan pun menjadi merasa nyaman dalam bekerja dan tidak ingin keluar atau mengundurkan diri.

Menurunnya biaya penghargaan pada tahun 2017 dibandingkan dengan tahun 2018 tidak berarti menurunnya kinerja dan prestasi kerja karyawan. Namun hal ini disebabkan oleh kebijakan manajemen untuk lebih selektif dalam menentukan kriteria-kriteria bagi karyawan yang berprestasi atau berjasa terhadap perusahaan. Hal ini juga disebabkan oleh kebijakan manajemen dalam hal kesejahteraan yang telah ditetapkan oleh perusahaan sehingga karyawan menjadi tidak manja dan semaunya, yang akan berdampak kerugian bagi perusahaan.

a. Kontribusi yang dilakukan PT. Armada Mix Banjarbaru kepada masyarakat sekitar perusahaan.

b. Kontribusi yang dilakukan PT. Armada Mix Banjarbaru terhadap lingkungan hidup di sekitar lingkungan perusahaan.

c. Kontribusi yang dilakukan PT. Armada Mix Banjarbaru terhadap sumber daya manusia baik itu karyawan perusahaan ataupun masyarakat sekitarnya

JIEB, Jilid 6, No 1,19 Maret 2020 ISSN Online 2615-2134 
d. Kontribusi yang dilakukan PT. Armada Mix Banjarbaru terhadap produk dan jasa serta pengembangannya.

2. Pendekatan Akuntansi Pertanggung jawaban Sosial yang dilakukan pada PT. Armada Mix Banjarbaru.

Pada PT. Armada Mix Banjarbaru pendekatan yang digunakan untuk pedoman pengukuran dalam pelaporan akuntansi pertanggungjawaban sosial sebagai berikut:

a. Pendekatan Deskriptif (the descriptive approach)

Dalam laporan sosial deskriptif pada perusahaan, informasi mengenai semua aktivitas sosial perusahaan dilaporkan dalam bentuk uraian (deskriptif) sehingga menguraikan aktifitas-aktifitas sosial perusahaan dalam bentuk pelaporan.

b. Pendekatan biaya yang dikeluarkan

Pendekatan biaya yang dikeluarkan menggambarkan semua aktivitas-aktivitas sosial perusahaan dikuantifikasikan dalam satuan uang, Sehingga laporan yang dihasilkan oleh pendekatan biaya yang dikeluarkan mempunyai kemampuan untuk diperbandingkan antara laporan suatu tahun tertentu, dengan laporan tahun yang lain.

c. Pendekatan biaya manfaat

Pendekatan biaya manfaat mengungkapkan baik biaya maupun manfaat dari aktivitas-aktivitas sosial perusahaan. dan untuk menerapkannya melihat alat ukur manfaat dari yang dihasilkan atas biaya yang telah dikeluarkan untuk semua aktivitas-aktivitas sosial perusahaan.

\subsection{Saran - Saran}

Dari hasil pembahasan dan kesimpulan yang diuraikan oleh penulis, maka saransaran yang dilakukan antara lain:

1. Memperhatikan lagi peningkatan persentasi untuk biaya- biaya yang dikeluarkan atas aktivitas- aktivitas sosial sehingga perhatian terhadap masyarakat dan lingkungan lebih diperhatikan lagi.

2. Perlu dialokasikan biaya sosial untuk kontribusi terhadap produk dan jasa, karena produk dan jasa yang dihasilkan oleh perusahaan tidak mungkin $100 \%$ tanpa cacat dan tentunya dengan adanya peningkatan penjualan maka laba yang diharapkan juga meningkat sehingga diharapkan adanya peningkatan untuk biaya sosialnya juga.

3. Melihat standar aturan dari pemerintah yang berisi tentang format baku laporan biaya sosial perusahaan sebagai bentuk tanggung jawab sosial perusahaan terhadap lingkungannya baik itu bentuk laporannya maupun besarnya proporsi biaya sosial tersebut terhadap penjualan atau laba bersih perusahaan.

4. Pemerintah dan Instansi terkait mempunyai tolok ukur dan penerapan aturan serta sosialisasi yang jelas terhadap perusahaan-perusahaan yang mempunyai atau tidak mempunyai tanggung jawab sosial pada lingkungan sekitarnya dan terhadap perusahaan yang tidak memenuhi aturan tersebut bisa dikenakan sanksi. 


\section{Daftar Pustaka}

Belkaoui, Ahmed R. 2009. Teori Akuntansi. Terjemahan. Yogyakarta : AK Group.

Diller, and Vernon. 2005. Accounting Theory. Third Edition. New York : John Willey \& Sons Inc.

Glautier, MWE., Underdown. 2006. Accounting Theory and Practice. Third Edition. London Pitman Publishing Ltd.

Harahap, Sofyan Syafri. 2005. Teori Akuntansi. Edisi Revisi. Jakarta : PT. Raja Grafindo Persada.
Lee, Robert K. 2009. Studi Kasus : Desain dan Metode. Jakarta: PT> Raja Grafindo Persada.

Sonhadji, Achmad. 2009. Akuntansi sosial :Peranannya dalam Mengukur Tanggung Jawab sosial Perusahaan, Suatu tinjauan Analitis. Akuntansi, No.10 (Oktober).

Usmansyah. 2009. Telaah alternatif Penerapan Akuntansi Pertanggung jawaban Sosial di Indonesia. Akuntansi, No.10 (Oktober). 